\begin{tabular}{|c|c|c|c|c|c|}
\hline $\begin{array}{l}\text { 2. ECN Category (mark one) } \\
\text { Supplemental } \\
\text { Direct Revision }\end{array}$ & $\begin{array}{l}\text { 3. Originator's Name, Orga } \\
\text { TD Torres, COGEM }\end{array}$ & $\begin{array}{l}\text { ization, MSIN, and Telepho } \\
\text { Engr, S7-90 } 372\end{array}$ & $\begin{array}{l}\text { No. } \\
173\end{array}$ & $\begin{array}{l}\text { SQ Required? } \\
\text { Yes } \square \text { No }\end{array}$ & $\begin{array}{l}\text { 5. Date } \\
8-11-00\end{array}$ \\
\hline $\begin{array}{l}\text { Change ECN } \\
\text { Temporary }\end{array}$ & $\begin{array}{l}\text { 6. Project Title/No. Work O } \\
\text { Hose in Hose Tra } \\
\text { Interim Stabiliz }\end{array}$ & $\begin{array}{l}\text { der No. } \\
\text { sfer Lines, } \\
\text { tion Engineering }\end{array}$ & $\begin{array}{l}\text { 7. Bldg./Sys./F } \\
241-S \text {, SX }\end{array}$ & $\begin{array}{l}\text { No. No. } \\
\text { and U }\end{array}$ & $\begin{array}{l}\text { 8. Approval Designator } \\
\text { ESQ }\end{array}$ \\
\hline $\begin{array}{l}\text { Standby } \\
\text { Supersedure } \\
\text { CancelNoid }\end{array}$ & $\begin{array}{l}\text { 9. Document Numbers Cha } \\
\text { sheet no. and rev.) } \\
\text { RPP-6153, Rev. O }\end{array}$ & ged by this ECN (includes & $\begin{array}{l}\text { 10. Related EC } \\
\text { N/A }\end{array}$ & $\mathrm{No}(\mathrm{s})$ & $\begin{array}{l}\text { 11. Related PO No. } \\
\text { N/A }\end{array}$ \\
\hline $\begin{array}{l}\text { 12a. Modification Work } \\
\square \text { Yes (fill out Blk. 12b) } \\
\bigotimes \text { No (NA Blks. 12b, } \\
\{2 \mathrm{c}, 12 \mathrm{~d} \text { ) }\end{array}$ & $\begin{array}{l}\text { 12b. Work Package No. } \\
\text { N/A }\end{array}$ & $\begin{array}{l}\text { 12c. Modification Work Co } \\
\text { N/A } \\
\text { Design Authority/Cog. En } \\
\text { Date }\end{array}$ & leted Signature \& & $\begin{array}{l}\begin{array}{l}\text { 12d. Restored } \\
\text { or Standk }\end{array} \\
\mathrm{N} / \mathrm{A} \\
\text { Design Autho }\end{array}$ & $\begin{array}{l}\text { to Original Condition (Temp. } \\
\text { y ECNs only) } \\
\text { ity/Cog. Engineer Signature \& } \\
\text { Date }\end{array}$ \\
\hline
\end{tabular}

Direct Revision of RPP-6153 Rev. 0 up to Rev.1.

14b. Justification Details

-This ECN reflects the inclusion of $241-U$ Tank Farm into the scope.

-This ECN also incorporates changes to chemical constituents for S/SX

tank farms.

-This ECN reflects the changes to the organization of personal.

-This modification will not change collective dose since it has no impact on radiological sources, contamination control or shielding.

-Design verification selected per HNF-IP-0842, Vol IV Sec. 4.2.4 is

informal review.

-USQ tracking number TE-00-0412 Rev.5.

\begin{tabular}{llllll}
\hline 15. Distribution (include name, MSIN, and no. of copies) & & \\
W. Zuroff & S7-24 & 1 & S. Swaney & S7-24 \\
K. Hull & T $4-07$ & 1 & M. Tipps & S7-34 \\
M. Koch & S7-24 & 1 & & \\
G. Barnes & S7-70 & 1 & & \\
T. Torres & S7 -70 & 1 & & \\
K. Ellingson & S7-24 & 1 & &
\end{tabular}

K. Ellingson

S7 -24

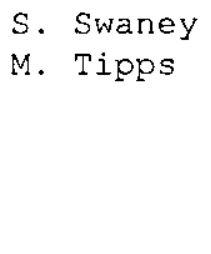

1

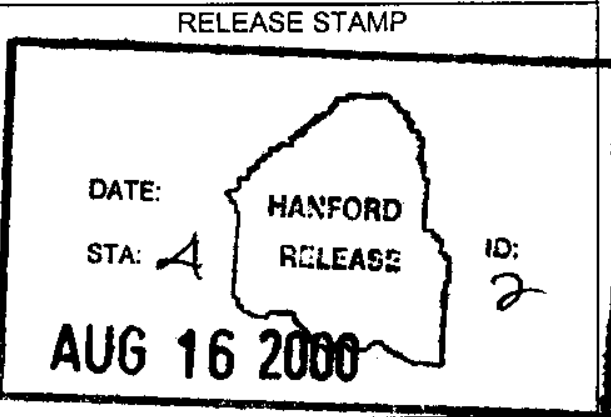


ENGINEERING CHANGE NOTICE

Page 2 of 2

1. $\mathrm{ECN}$ (use no. from pg. 1) 661685

16. Design Verification Required

ENGINEERING

\section{$\square$ Yes \\ $\bigotimes$ No}

17. Cost Impact
ENGINEERING
Additional $\square \$ \underline{N / A}$
Savings $\square \$ \mathrm{~N} / \mathrm{A}$

ב.

Additional $\square$

\section{CONSTRUCTION}

$\$ N / A$

$\$ N / A$
18. Schedule Impact (days)

Improvement

$N / A$

Delay

$\square$ N/A

19. Change Impact Review: Indicate the related documents (other than the engineering documents identified on Side 1) that will be affected by the change described in Block 13. Enter the affected document number in block 20.

\begin{tabular}{|c|c|c|c|}
\hline SDD/DD & $\square$ & Seismic/Stress Analysis & Tank Calibration Manual \\
\hline Functional Design Criteria & $\square$ & Stress/Design Report & Health Physics Procedure \\
\hline Operating Specification & L & Interface Control Drawing & Spares Multiple Unit Listing \\
\hline Criticality Specification & $\square$ & Calibration Procedure & Test Procedures/Specification \\
\hline Conceptual Design Report & $\square$ & Installation Procedure & Component Index \\
\hline Equipment Spec. & $\square$ & Maintenance Procedure & ASME Coded Item \\
\hline Const. Spec. & L & Engineering Procedure & Human Factor Consideration \\
\hline Procurement Spec. & L & Operating Instruction & Computer Software \\
\hline Vendor Information & L & Operating Procedure & Electric Circuit Schedule \\
\hline OM Manual & 匚 & Operational Safety Requirement & ICRS Procedure \\
\hline FSAR/SAR & $\square$ & IEFD Drawing & Process Control Manual/Plan \\
\hline Safety Equipment List & [ & Cell Arrangement Drawing & Process Flow Chart \\
\hline Radiation Work Permit & E & Essential Material Specification & Purchase Requisition \\
\hline Environmental Impact Statement & $\square$ & Fac. Proc. Samp. Schedule & Tickler File \\
\hline Environmental Report & $\square$ & Inspection Plan & $\underline{N} / \mathrm{A}$ \\
\hline Environmental Permit & $\square$ & Inventory Adjustment Request & \\
\hline
\end{tabular}

$\square$

Functional Design Criteria

Stress/Design Report

Interface Control Drawing

Spares Multiple Unit Listing

Criticality Specification

Calibration Procedure

Test Procedures/Specification

Conceptual Design Report

Maintenance Procedure

ASME Coded Item

Const. Spec

Engineering Procedur

Human Factor Consideration

Procurement Spec

Operating Instruction

Computer Sotware

Vendor Information

Operational Safety Requirement

ICRS Procedure

FSAR/SAR

Signatures below indicate that the signing organization has been notified of other affected documents listed below.

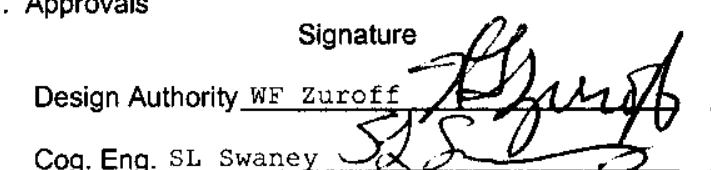

Cog. Eng. SL Swaney $S 2$

Cog. Mgr. MR Koch 2/hhdrd

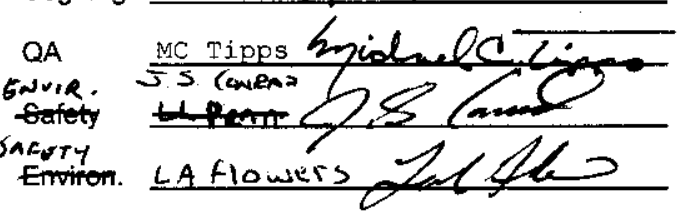

Other

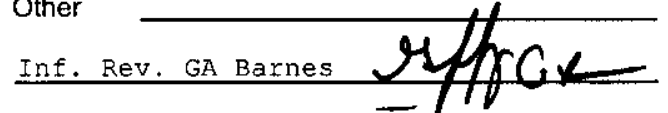

TD Torres Tipena Tevoes

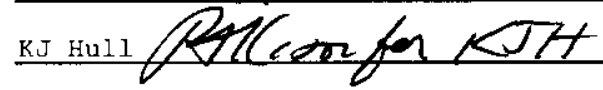

Design Agent

PE

QA

Safety

Design

Environ.

Other

\section{DEPARTMENT OF ENERGY}

Signature or a Control Number that tracks the Approval Signature

ADDITIONAL 


\title{
Engineering Task Plan for Hose-in-Hose Transfer Lines for the Interim Stabilization Program
}

\author{
TD Torres \\ COGEMA Engineering \\ Richland, WA 99352 \\ U.S. Department of Energy Contract DE-AC06-96RL13200

\begin{tabular}{|c|c|c|c|}
\hline $\begin{array}{l}\text { EDT/ECN: } \\
\text { Org Code: } \\
\text { B\&R Code: }\end{array}$ & 661685 & $\begin{array}{l}\text { UC: N/A } \\
\text { Charge Code: } \\
\text { Total Pages: }\end{array}$ & 33 \\
\hline
\end{tabular}

Key Words: S/SX Tank Earms, U Tank Farms, Engineering Task Plan, Hose-inHose Transfer Lines, INterim Stabilization Program, Over Ground Transfer Lines, Transfer Iine Assemblies

Abstract: The document is the Engineering Task Plan for the engineering, design services, planning, project integration and management support for the design, modification, installation and testing of an over ground transfer (OGT) system to support the interim stabilization of $\mathrm{S} / \mathrm{SX}$ and $\mathrm{U}$ Tank Farms.

TRADEMARK DISCLAIMER. Reference herein to any specific commercial product, process, or service by trade name, trademark, manufacturer, or otherwise, does not necessarily constitute or imply its endorsement, recommendation, or favoring by the United States Government or any agency thereof or its contractors or subcontractors.

Printed in the United States of America. To obtain copies of this document, contact: Document Control Services, P.O. Box 950, Mailstop H6-08, Richland WA 99352, Phone (509) 372-2420; Fax (509) 376-4989.
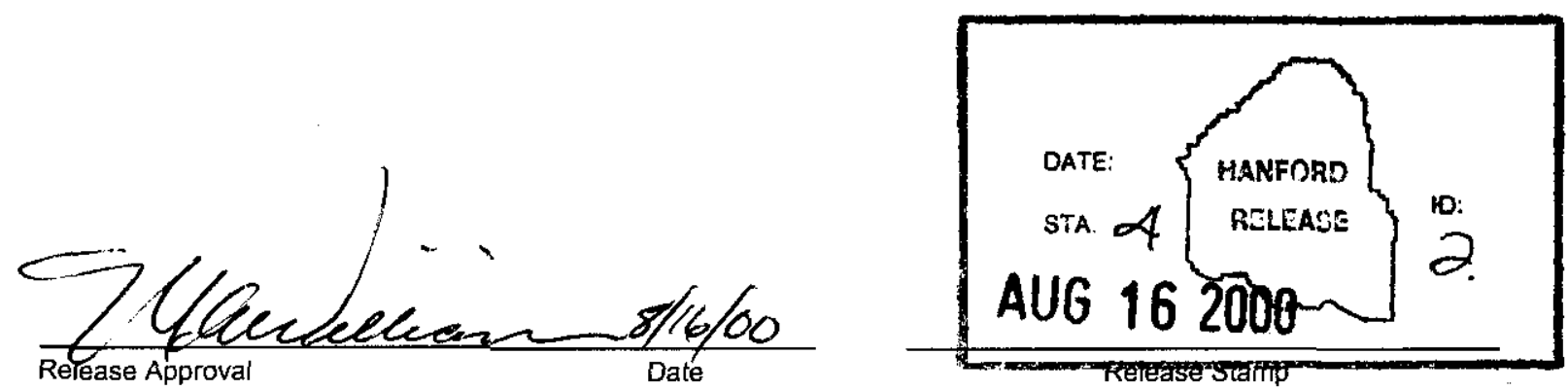

Approved For Public Release 


\section{RECORD OF REVISION}

(2) Title

Engineering Tack Plan for Hose-in-Hose Transfer System for the Interim Stabilization Program

Change Control Record

(3) Revision

(7)

$0 \quad$ Revision 0 released via EDT-628307

1 RS

Revision 0 released via EDT-628307

(4) Description of Change - Replace, Add, and Delete Pages

Revision 1 released via ECN-661685. Replaces all

pages of Revision 0 .
(1) Document Number

RPP -6153

Page 1

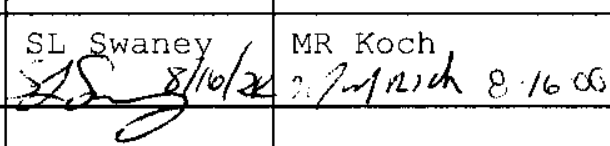

Authorized for Release

\begin{tabular}{l|ll} 
(5) Cog. Engr. & (6) Cog. Mgr. Date
\end{tabular}

JJ Elsen MR Koch

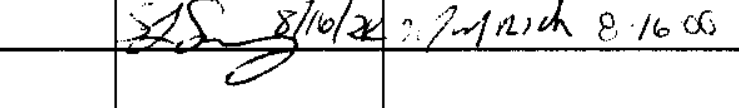


RPP-6153 Rev. 1

ENGINEERING TASK PLAN

FOR

HOSE-IN-HOSE TRANSFER SYSTEM FOR THE INTERIM STABILIZATION

PROGRAM

By

M. P. Rung

COGEMA Engineering Corporation 


\section{TABLE OF CONTENTS}

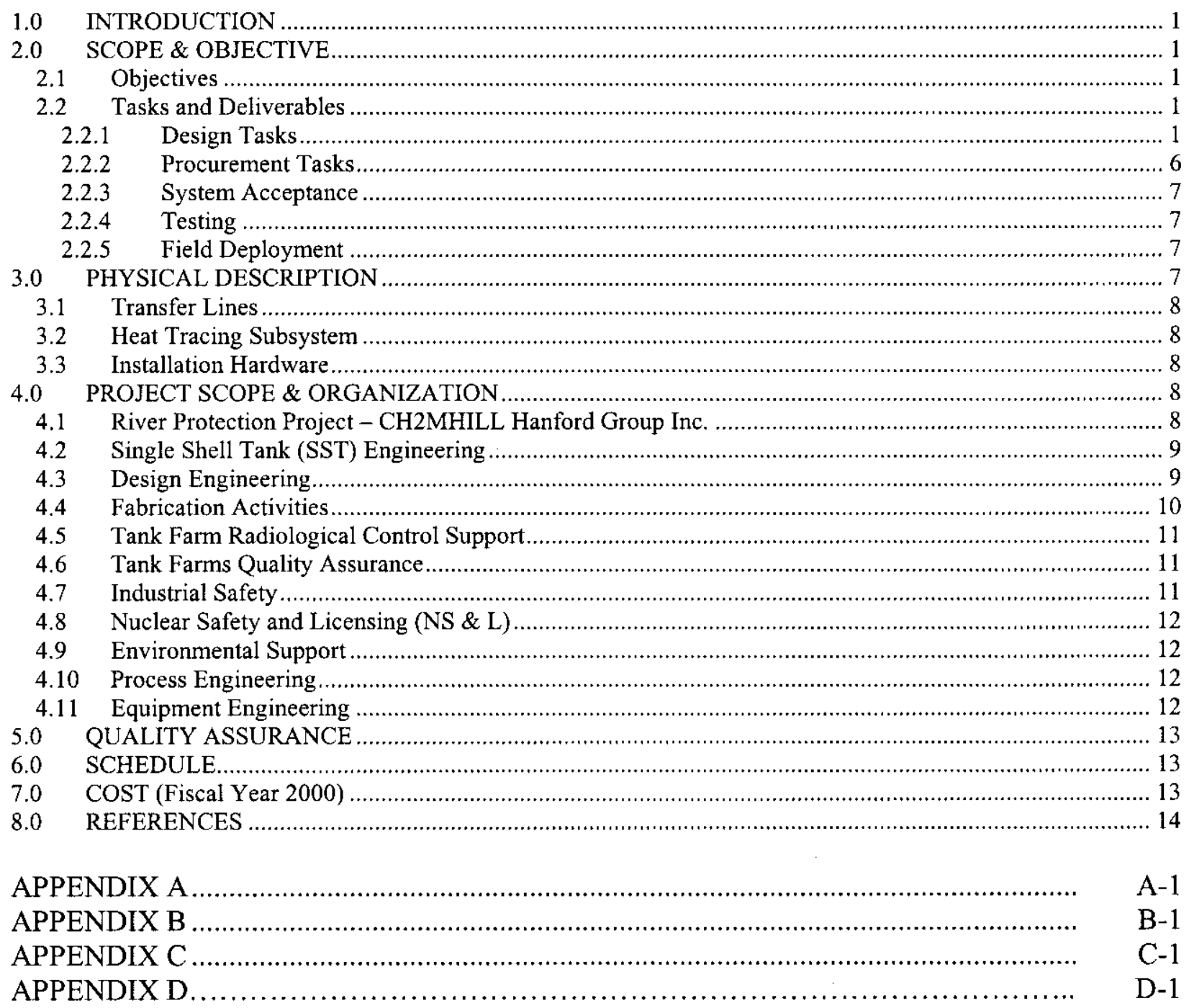




\section{ENGINEERING TASK PLAN \\ FOR HOSE-IN-HOSE TRANSFER SYSTEM FOR THE INTERIM STABILIZATION PROGRAM}

\subsection{INTRODUCTION}

In order to complete the interim stabilization of Single Shell Tanks (SSTs) in the 241-S, 241-SX and 241-U Tank Farms, pumpable liquids must be removed from all of the SSTs in these farms. This task is to provide a double encased hose-in-hose transfer line, suitable for placement on or near the soil surface to be used to convey pumpable liquids from the tanks in these farms to valve pits where the liquids can be routed as desired. See Figure 1 for the $241-\mathrm{S}$ and SX Tank Farms pumping plan and Figure 2 for the 241-U Tank Farm pumping plan. The Interim Stabilization Program is to supply pumps and piping jumpers required to retrieve pumpable liquids for conveyance by the double encased transfer lines.

This plan describes the effort necessary to provide the engineering, design services, planning, project integration and management support for the design, modification, installation and testing of hose-in-hose transfer lines to support interim stabilization in 241-S, 241-SX and 241-U Tank Farms.

This plan does not include the effort necessary to review for repairing existing transfer system equipment or installing transfer lines for other tank farms. However, a preliminary engineering design to replace BY Farm transfer line supporting BY $105 \& 106$ will be completed by September 30, 2000.

\subsection{SCOPE \& OBJECTIVE}

\subsection{Objectives}

The objective is to design, provide, install and test, hose-in-hose waste transfer assemblies, as shown in Figure 3, so that the Interim Stabilization Program can connect to these transfer lines to pump liquids from nine single shell tanks as shown in Figure 1. The design shall include consideration for removal and disposal of the waste transfer lines.

\subsection{Tasks and Deliverables}

The deliverables associated with this work scope include the following

\subsubsection{Design Tasks}

Task 1 - Develop Engineering Task Plan. An engineering task plan prepared in accordance with the guidance provided in RPP-PRO-1819 will cover the engineering, design services, planning, project integration and management support for the design, modification, installation, testing, fabrication, and deployment of hose in hose transfer lines. This plan will delineate which company, organization or department is responsible for each deliverable and how the parties interface with each other. The functional requirements and technical criteria for transfer lines are included in Appendix A of this document. 


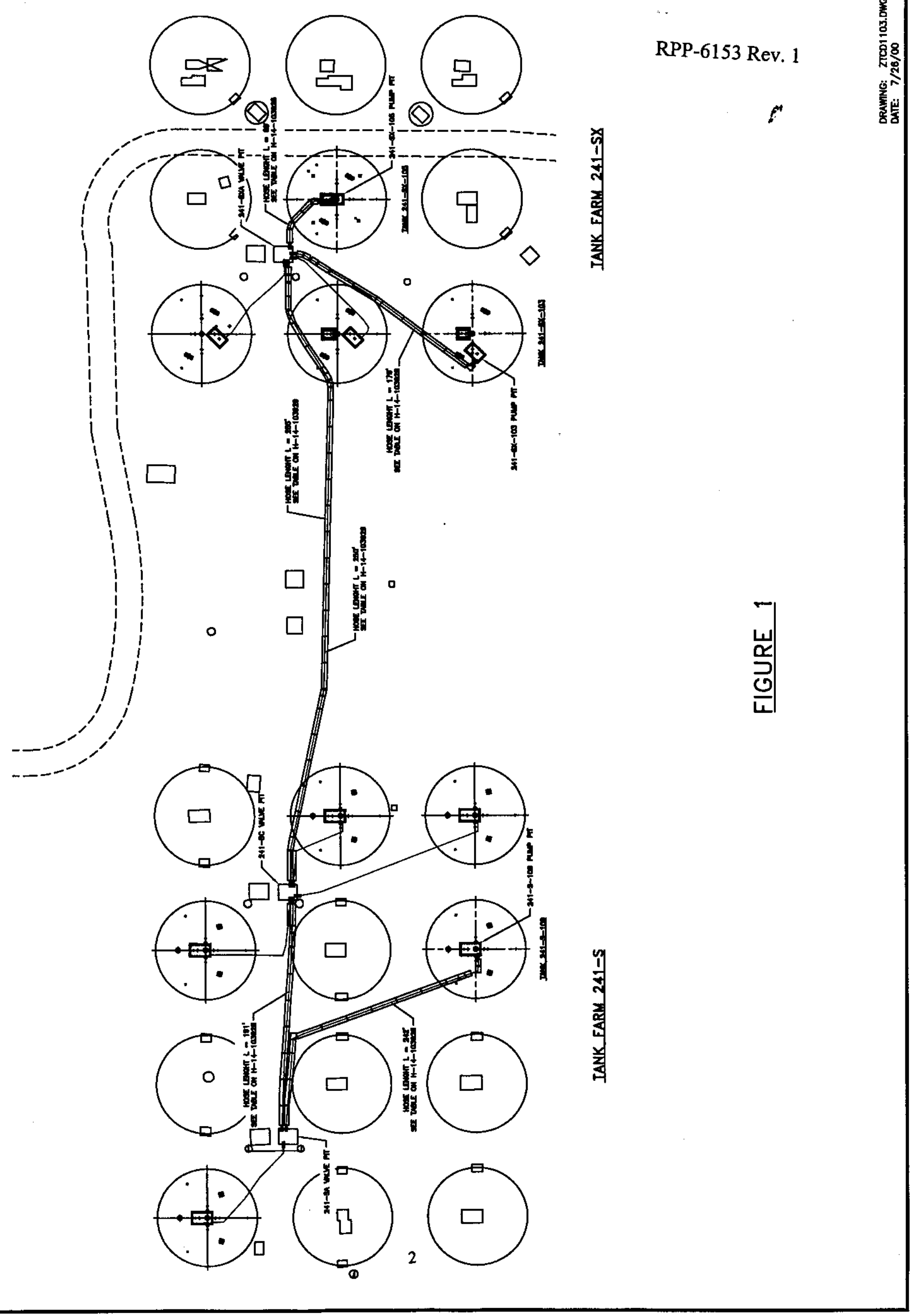



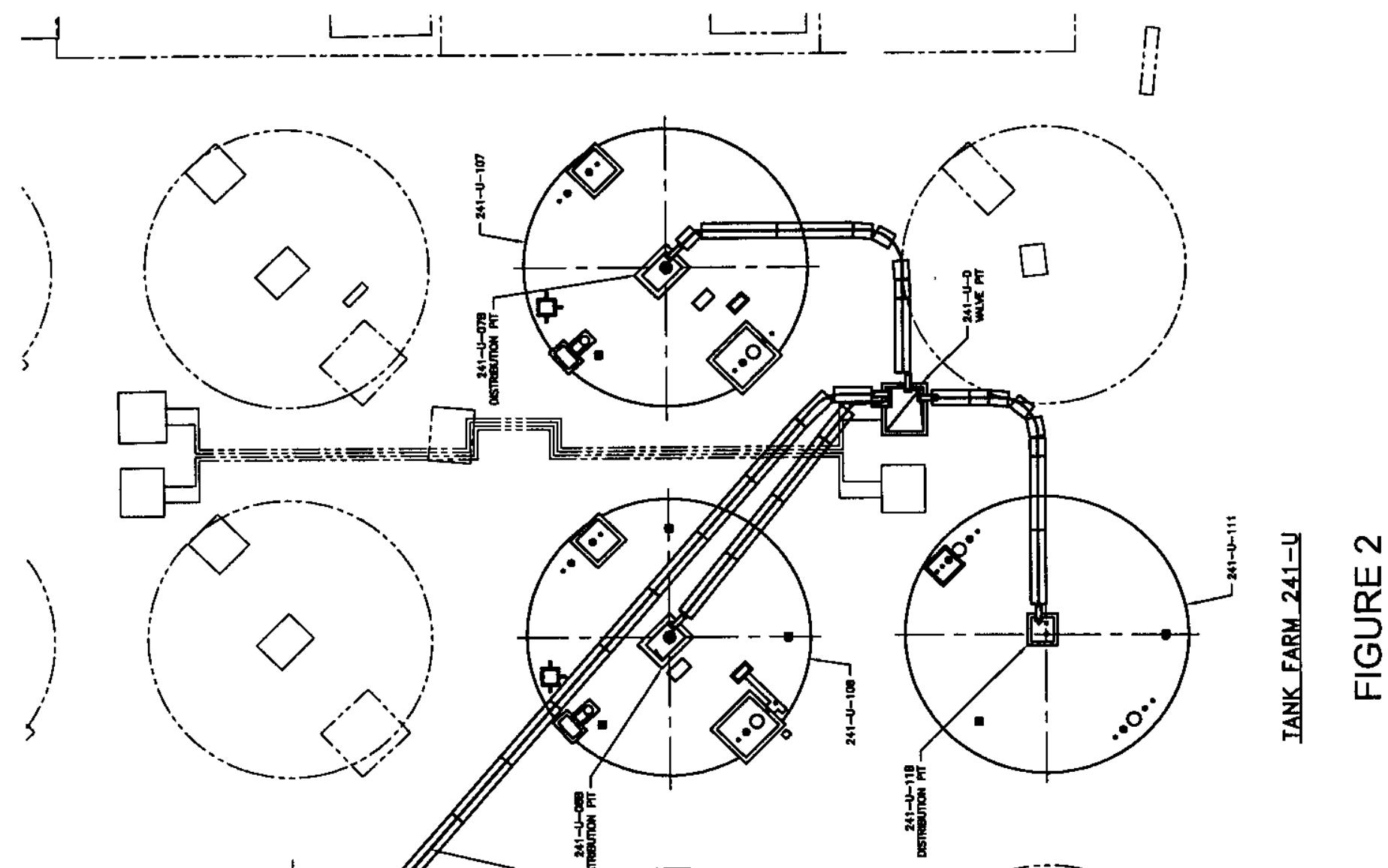

1
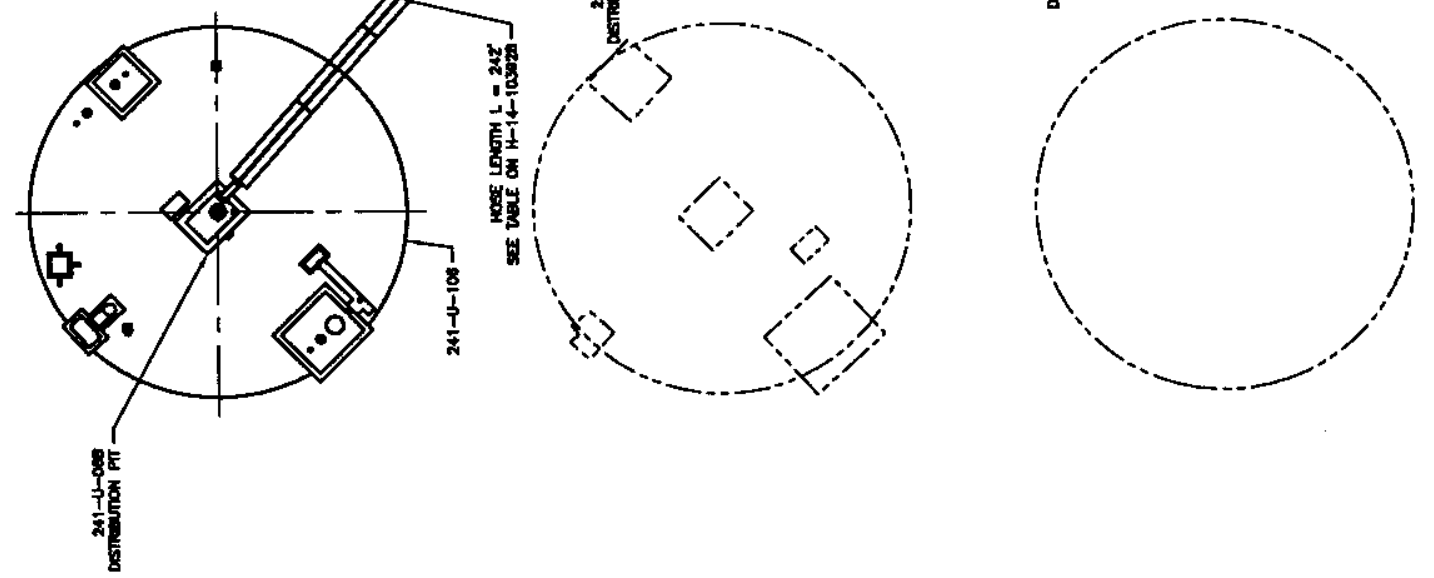

$\leftrightarrow$ 


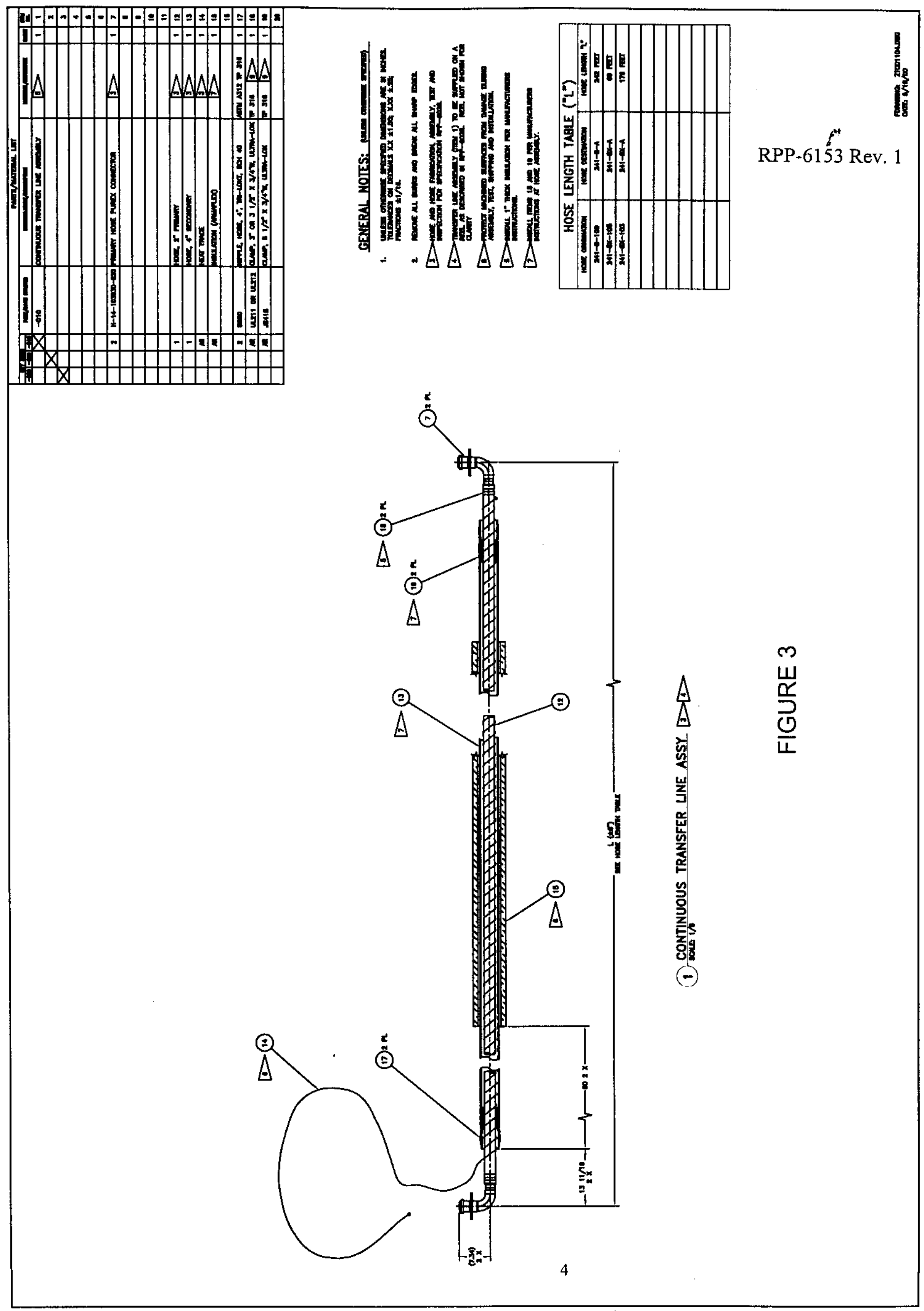


Task 2 - Prepare Interface Drawings. The interface for hose-in-hose transfer lines will be developed based on the functional requirements and technical criteria and the existing tank systems and structures. Interface drawings will include installation details for transfer line equipment where they mate with existing and planned pit covers. Interfaces with electrical systems for hose heat tracing will also be developed.

Task 3 - Prepare a Design. Based on the functional requirements and technical criteria provided in Appendix A, and current River Protection Project (RPP) procedures including HNF -IP-0842 and RPP-PRO-097, a design and procurement specification(s) shall be prepared. The design will include considerations for field installation and operation and hose-in-hose removal and disposal. The hose-in-hose transfer lines will be fabricated and tested by an established hose assembly manufacturer off-site. Some system components may be built on site. The design will rely on existing leak detectors in valve and pump pits. Subsystems within the cognizance of this task plan include:

- Hose-in-Hose transfer lines

- Electrical power (for heat tracing)

- Installation hardware/structures, including shielding box assemblies and shielding plates

For a conceptual description see Section 3.0. For each of these systems several general scope requirements will apply.

The following will be included as part of the design as required:

- Fabrication drawings and test procedures will be developed and issued

- H-14 drawings for the transfer lines and components will be prepared and approved

- A structural analysis report covering the system configuration will be prepared and issued

- Engineering Change Notices (ECNs) will be issued as required to reflect the new proposed field configuration.

Additional documentation will include:

- Test Reports

- Vendor Information Data \& Index

- ALARA checklist/dose rate calculation(s)

- As-built drawings

- Commercial Grade Item dedication forms

- Applicable Tank Dome Loading Analysis

- Unreviewed Safety Questions (USQs) 
Task 4 -Integrity Assessment. A review of the system integrity of the new systems, structures and components added by this project will be conducted by an independent qualified professional engineer as required and defined in Washington Administrative Code 173-303-640. This review will include the design, installation and testing of the system. Any recommendations shall be incorporated before the transfer lines are used.

Task 5 - Structural Analysis. The analysis of the transfer system configuration will be reviewed and revised as necessary to ensure tank integrity. Dome loading, seismic and wind loads, missile impacts on shielding box assemblies and shielding plate loading will be considered. An overall structural analysis report will be prepared and issued.

Task 6-Identify Required Environmental Documentation. An evaluation will be performed to identify applicable environmental permits or Notice of Construction(s). If required, the permitting process will be initiated. The scope of this work plan is limited to a level of effort required to support the development of required environmental documentation. The definition and creation of any environmental permitting is the responsibility of the Interim Stabilization Program.

Task 7 - Perform Safety Analysis. Safety analysis and hazards evaluations of the proposed transfer lines must be completed before transfer lines can be used. The scope of this task plan is limited to a level of effort required to support the development of a safety analysis. The definition and creation of a safety analysis is the responsibility of the Interim Stabilization Program. It is planned that an unresolved safety question (USQ) or unresolved safety question determination (USQD) can be used to allow the use of the hose-in-hose transfer system for this application.

Task 8 - Interface with Fabrication and QA/QC Personnel. Interfaces will be maintained between 200 Area Site Fabrication Services and engineering design team members. Project personnel shall also interface as required with cognizant QA/QC personnel.

\subsubsection{Procurement Tasks}

Task 1 - Procurement Specifications. Procurement specifications will be developed based on the functional requirements and technical criteria provided in Appendix A.

Task 2 - Procure Equipment and Materials. Safety Class and Safety Significant items will be procured in accordance with HNF -IP-0842 Volume IV, Section 5.13,

Procurement of Safety Class Items and Management of Spares. General service items will be procured in accordance with RPP-PRO-268, Control of Purchased Items and Services. Engineering personnel shall provide assistance to procurement and quality organizations in support of these activities.

Task 3 - Travel/Source Inspections. Equipment or materials requiring on-site inspection or acceptance shall be supported. 


\subsubsection{System Acceptance}

Task 1 - Acceptance Criteria. Acceptance criteria will be developed for all equipment fabricated or delivered. For equipment fabricated on-site, an acceptance plan will be defined in the design media. For equipment procured off-site, the acceptance criteria will be detailed in the procurement specifications.

Task 2 - Commercial Grade Item Dedications. Commercial Grade Item (CGI) Dedication forms will be completed as required for Safety Class or Safety Significant items as per HNF-IP-0842, Vol. IV, Sec. 3.11, Replacement Item Evaluation, Commercial Grade Item Dedication and Vol. IV, Sec. 5.13, Procurement of Safety Class Items and Management of Spares.

\subsubsection{Testing}

Task 1 -Vendor Testing. The hose-in-hose assemblies will be tested at the vendor's facility. Additional components may be tested on site if necessary.

Task 2 - Acceptance Testing. An Acceptance Testing Procedure (ATP) will be prepared and conducted for the identified equipment. Upon completion of testing, an Acceptance Test Report (ATR) shall be generated and released.

\subsubsection{Field Deployment}

Task 1 - Training. Training will be supported as required. The development of training plans will be the responsibility of Interim Stabilization. Engineering shall provide assistance as requested.

Task 2-Field Assembly and Installation Support. A planner will be provided by Interim Stabilization Engineering for the preparation of work packages for field assembly and installation. Engineering support for this task shall be provided by Interim Stabilization, as required.

Task 3 -Operational Support. Support will be provided by Interim Stabilization to Operations for the development of required operational procedures or modifications to procedures.

Task 4 - Start-up. Assistance with start-up and operation will be provided on an asneeded basis.

\subsection{PHYSICAL DESCRIPTION}

This section defines each subsystem in sufficient detail to allow distinct work scopes to be developed for each subsystem. The distinction between each subsystem is provided by:

- providing a general physical description

- describing the general function of each subsystem

- identifying where each sub-system interface begins and ends. 
Transfer line assemblies include:

- double contained, hose-in-hose, transfer line assemblies (see Figures 1,2 and 3)

- heat tracing subsystem connected to existing electrical power

- installation hardware/structures.

\subsection{Transfer Lines}

The transfer line assemblies (of various lengths) consist of a 2" nominal diameter primary hose wrapped in heat tracing and inserted into a 4" nominal diameter secondary hose. Appropriate end connectors will be attached to each end of the primary and secondary hoses to mate-up with piping jumpers supplied and installed by others. The outer hose will be insulated. The transfer line assemblies will be installed on the ground or in the ground no more than 12" deep. A protective and/or radiation shielding cover will be placed over each transfer line assembly. The functional requirements and technical criteria for these assemblies are provided in Appendix A. See Figure 3 for a conceptual design of a typical hose-in-hose transfer line assembly.

\subsection{Heat Tracing Subsystem}

The 2" nominal diameter primary hose will be wrapped with heat tracing to aid in maintaining acceptable temperatures within the wastes being transferred. Electrical power (tapped from some convenient location) will be required.

\subsection{Installation Hardware}

Hardware will be developed as required to ensure a safe and reliable installation. The installation hardware will be defined during the detailed design. Some examples of installation hardware may include transfer line anchorage assemblies (hose saddles), road crossing protective trenching and heat tracing mounting rack(s). Existing valve and pump pit cover blocks will be modified or new steel cover plates will be fabricated for pits to allow installation of the hose-inhose transfer line assemblies. Shield box assemblies will be installed around the transfer line assemblies when they loop over the wall of the pump and valve pits.

\subsection{PROJECT SCOPE \& ORGANIZATION}

A procurement specification will be written for the design, fabrication, testing and delivery of the transfer line assemblies. Some or all end connections may be fabricated at Hanford and shipped to the fabricator of the transfer line assemblies to ensure proper mate-up. Other portions of this work scope will be designed on-site.

The program/project organization to complete the work is provided in Section 4.1 through 4.12.

\subsection{River Protection Project - CH2MHILL Hanford Group Inc.}

CH2MHILL Hanford Group Inc. (CHG) has the overall responsibility for this effort. CHG has assembled a team for this effort under the control of the Interim Stabilization Program. Support staff from various other departments within CHG will be used when needed to augment the Interim Stabilization Program staff. Interim Stabilization Program will provide funding and overall management/direction. Key organizations and personnel are listed below. 


\section{Interim Stabilization Program:}

Director: T. L. Hissong

Programs Manager: D. J. Saueressig

\section{Interim Stabilization Engineering:}

Cognizant Engineering Manager: M. R. Koch

Interim Stabilization Design Authority: W. F. Zuroff

Interim Stabilization Cognizant Engineer: J. J. Elsen - S and SX Farms

Interim Stabilization Cognizant Engineer: S. L. Swaney - U Farm

Interim Stabilization Operations Manager: M. N. Johnson

Interim Stabilization "Person-in-Charge (fieldwork supervisor): J. L. Hawley/C. W. Peoples

Responsibilities:

Interim Stabilization will have full responsibility and cognizance for the design, installation, and testing of the transfer system prior to formal turnover. Interim Stabilization will participate in the design and fabrication efforts, as an observer, as a minimum.

- Approve revised functions and criteria

- Prepare work package(s) for electrical modifications

- Prepare work package(s) to install the hose-in-hose transfer lines

- Install the hose-in-hose transfer lines

- Perform operational test procedures (OTPs) and functional checks

- Review and approve operating, training and maintenance procedures

- Perform any operational readiness activities

- Accept ownership of the hose-in-hose transfer lines prior to operation

- Operate the equipment when installed

\subsection{Single Shell Tank (SST) Cog Engineering}

S/SX, U and BY Farms Cognizant Engineering Manager: W. E. Bryan S/SX Farms Cognizant Engineer: J. N. Doeler

U Farm Cognizant Engineer: K. J. HullS/SX and UFarms Design Authority: P. F. Kison

SST Engineering will assume engineering responsibility and cognizance of the transfer system after formal turnover.

- Review design basis and technical documentation

- Approve design basis and technical documentation and revisions (only Cognizant Engineer, J. N. Doeler or K. J. Hull approval required)

\subsection{Design Engineering}

Design Engineering Manager: C. E. Hanson (COGEMA Engineering Corporation)

Technical Lead: G. A. Barnes

Engineering/Operations Liason: J. R. Biggs 
A multi-company group has been assembled under the design engineering management of C. E. Hanson to conduct/coordinate all of the design, procurement, fabrication, acceptance testing, and product delivery of the hose-in-hose transfer lines for the Interim Stabilization Program. To accomplish this task, a design engineering team and support staff has been assembled to complete the following:

- Prepare this task plan

- Assemble the core team as identified in the following sections

- Delegate the responsibility for the deliverables listed in Section 2

- Identify necessary analysis

- Assist in the coordination of presentations

- Define scope for transfer system-related activities

- Perform cost estimating

- Status overall design effort

- Schedule activities

- Initiate, review and approve procurement of contracts for fixed scope deliverables

- Review, approve, and issue pertinent documents into the PHMC system

- Prepare appropriate commercial grade item (CGI) dedication for vendor fabrication

- Identify required manpower resources

- Provide direction for as-building and design changes

- Direct fabrication shop work as required

- Provide unreviewed safety questions (USQs)

- Prepare Engineering Change Documentation and associated USQs

- Prepare, check and issue mechanical, electrical, and instrument drawings

- Revise drawings/sketches as required

- Review supporting structural design criteria document and revise as necessary

- Provide report(s) documenting the results of all analyses.

- Prepare and issue acceptance test reports (ATRs)

- Specify the QC inspections required and any material requirements

- Prepare and release Acceptance for Beneficial Use to fulfill checklist in Appendix A

The responsibilities associated with this work plan include coordination with other organizations to reach scope, schedule and cost agreement, all approvals and any necessary support.

\subsection{Fabrication Activities}

Site Fabrication Services Manager: M. A. Butterworth

Site Fabrication Supervisor: L. A. Mercer

Fabrication of selected items needed for transfer line components will be performed on the Hanford site by Site Fabrication Services (Dyncorp). The design team will provide technical direction to the fabrication organization. Site Fabrication Services will be responsible for cost and schedule commitments of fabrication activities. The design team will be responsible for the following:

- Provide all project management and coordination between the design team and Site Fabrication Services

- Provide design

- Provide work order number 
- Provide technical direction for any procurement

- Provide technical direction for fabrication work and inspections

- Provide all quality control (QC) inspection criteria

- Approve the turnover package developed by Site Fabrication Services

The safety classification and the approval levels of this task are described in detail in Section 7.0 (Quality Assurance). Shipping and handling instructions will be developed after the design is sufficiently developed.

\subsection{SST Radiological Control}

Radiological Control Manager: K. W. Gray

Radiological Control Engineers: D. J. Foust

Responsibilities:

- Participate as a design and fabrication team member

- Provide radiological support as a point of contact

- Prepare or assist in preparation of ALARA Management Worksheets (AMWs)

- Support the preparation of work plans for the installation of the hose-in-hose transfer system

- Review training, operating and maintenance procedures as required

- Assist in preparation of the ALARA design review and coordinate reviews required with the ALARA chairman

\subsection{SST Quality Assurance}

Quality Assurance Manager: M. A. Wright

Quality Assurance Engineers: M. C. Tipps

Responsibilities:

- Participate as a design and fabrication team member as Quality Assurance Representative

- Provide Quality Assurance support. Support the review and approval of work plans for the installation of the hose-in-hose transfer system.

- Review training, operating and maintenance procedures as required

\subsection{Industrial Safety}

Industrial Safety Manager: M. T. Hughey

Industrial Safety Engineer: L. A. Flowers

Responsibilities:

- Participate as a design review team member

- Provide Industrial Safety support

- Review and approve the installation of the hose-in-hose transfer system

- Review training, operating and maintenance procedures 


\subsection{Nuclear Safety and Licensing (NS \& L)}

NS \& L Manager: C. E. Leach

NS \& L Engineer: R. D. Smith

Responsibilities:

- Review all designs generated. Perform safety analysis as required to address the installation, operation, modifications and removal of the hose-in-hose transfer system.

- Provide new controls if necessary and prepare authorization basis $(\mathrm{AB})$ revision documents.

\subsection{Environmental Support}

Environmental Manager: B. G. Erlandson

Environmental Representative: P. C. Miller

Responsibilities:

- Provide dedicated environmental review of documentation.

- Negotiate the environmental controls with the Washington State Department of Ecology and other regulators, as required, for this program.

\subsection{Process Control}

Process Engineering Manager: N. W. Kirch

Process Engineering Lead: D. A. Reynolds

Responsibilities:

- Review the hose-in-hose transfer system functional requirements and technical criteria

- Provide general support

\subsection{Plant Support Engineering}

Plant Support Manager: A. H. Friberg

Maintenance tasks will be completed in support of the hose-in-hose transfer system. The Vendor Information (VI) data shall be complete and available for procedure verification. A VI index will be developed that will provide the equipment label, a brief description of the equipment and give the VI file and supplement number for each piece of equipment. Design Engineering is responsible for the development of the Vendor Information List, if required per HNF-IP-0842, IV, 4.23. The list will be released as a supporting document. 


\subsection{QUALITY ASSURANCE}

The "quality" management system for this activity is designed to achieve project control and meet our customer's quality requirements as specified in 10 CFR 830.120, Quality Assurance. Additional customer quality requirements are derived from the Hanford Federal Facility Agreement and Consent Order (Tri-Party Agreement) (Ecology et al. 1994). These quality requirements are transmitted to this activity through RPP-MP-600, Quality Assurance Program Description (draft).

\subsection{SCHEDULE}

The schedule for this task is provided as Appendix C. This schedule was defined for Fiscal Year 2000 and will be updated when the budget is finalized.

\subsection{COST (Fiscal Year 2000)}

Engineering, Procurement, Fabrication and Construction Cost Estimate. This cost estimate was defined for Fiscal Year 2000 and will be updated when the budget is finalized.

\begin{tabular}{|c|c|c|}
\hline Hose & $\$ 200,000$ & $(\$ 169 /$ foot for 1,186 feet $)$ \\
\hline Shielding & $\$ 190,000$ & ( $\$ 126 /$ foot for 2" $\times 44^{\prime}-0$ CS plate) \\
\hline Shielding Rework & $\$ 25,000$ & \\
\hline Hose End Connections & $\$ 25,000$ & \\
\hline Pit Hose Support Assemblies & $\$ 30,000$ & \\
\hline Heat Tracing Stands & $\$ 30,000$ & \\
\hline Hose Line Connections & $\$ 15,000$ & \\
\hline Shielding Box Assemblies & $\$ 75,000$ & \\
\hline Design Team & & \\
\hline - Engineers & & \\
\hline - Designers & & \\
\hline - Operations/Engr. $s$ & & \\
\hline - Planning & $\underline{\$ 671,000}$ & subtotal \\
\hline & $\$ 1,261,000$ & Total \\
\hline
\end{tabular}

Assumptions:

1. Design and fabrication of pump and valve pit covers are by others.

2. Design, fabrication, installation/modification of pit jumpers are by others. 


\subsection{REFERENCES}

AASTHO, 1989, Standard Specifications for Highway Bridges, $14^{\text {th }}$ edition, American Association of State Highway and Transportation Officials

ASCE, 1998, Minimum Design Loads for Buildings and Other Structures, American Society of Civil Engineers standard 7-98

CHG Interoffice Memo File No. 74B20-00-047, Chemical Characteristics for Liquid Waste in S and SX Tank Farms, August 2000.

CHG Interoffice Memo File No. 74820-00-048, Chemical Characteristics for Liquid Waste in U Tank Farm, August 2000.

HNF-5183, Rev. 0, Tank Farm Radiological Control Manual, CH2M Hill Hanford Group, Inc., Richland, Washington

HNF-SD-WM-SAR-067, Facility Safety Analysis Report, Rev. 1-H

HNF-SD-WM-TSR-006, Technical Safety Requirements, Rev. 1-H

Manual of Steel Construction, 9th Edition, American Institute of Steel Construction, Inc. One East Wacker Drive, Suite 3100, Chicago, IL 60601-2001

RPP-IP-0842, RPP Administration, CH2M Hill Hanford Group, Inc., Richland, Washington

RPP-PRO-097, Rev 0, Engineering Design and Evaluation, CH2M Hill Hanford Group, Inc. Richland, Washington

RPP-PRO-268, Rev. 1, Control of Purchased Items and Services, CH2M Hill Hanford Group, Inc. Richland, Washington

RPP-PRO-1621, Rev. 0, ALARA Decision-Making Methods, CH2M Hill Hanford Group, Inc. Richland, Washington

RPP-PRO-1622, Rev. 0, Radiological Design Review Process, CH2M Hill Hanford Group, Inc. Richland, Washington

RPP-PRO-1819, Rev. 0, Engineering Requirements, CH2M Hill Hanford Group, Inc. Richland, Washington

WAC 173-303, Dangerous Waste Regulations, Department of Ecology, Washington Administrative Code, State of Washington, Olympia, Washington 
RPP-6153 Rev. 1

APPENDIX A

FUNCTIONAL REQUIREMENTS AND TECHNICAL CRITERIA 


\section{APPENDIX A \\ Functional Requirements and Technical Criteria}

\section{Hose-In-Hose Transfer Line Assemblies}

Application: Transfer of radioactive mixed waste in support of tank stabilization operations.

Description: Double contained transfer line, hose in hose, suitable for placement on or near soil surface.

Functional requirements:

- Primary (inner) hose rated working pressure shall be not less than 375 psig.

- Secondary (outer) hose rated working pressure not less than 60 psig and shall withstand vacuum to a negative 6 inches water column.

- Primary hose burst pressure rating not less than 1500 psig.

- Secondary hose burst pressure rating not less than 300 psig.

- Primary hose tensile strength capable of withstanding axial load equal to weight of hose filled with fluid of specific gravity equal to 1.5 with a factor of safety equal to 2.25 .

- Secondary hose tensile strength capable of withstanding axial load equal to weight of hose filled with fluid of specific gravity equal to 1.5 with a factor of safety equal to 2.25 .

- Both primary and secondary hoses shall be manufactured in such a manner as to prevent the build up of static charge between the two during their assembly, installation, operation, and dismantling. The use of anti-static rubber products meeting the definition of ASTM D991, Standard Test Method for Rubber Property - Volume Resistivity of Electrically Conductive and Anti-Static Products (resistance between $10^{4}$ and $10^{11} \mathrm{ohms}$ ) is required for inner and outer surfaces of the secondary encasement hose, and for the outer surface of the primary hose.

- The primary chemical constituents of the waste to be transferred and their concentration prior to dilution are given in the Chemical Constituents of Undiluted Waste tables below. Table 1 lists chemicals of concern for S/SX Tanks Farms and Table 2 lists chemicals of concern for U Tank Farm as provided from memo in Appendix D. Transfer line materials of construction shall be compatible with the specified waste. Both the primary and secondary hoses shall be of ethylene propylene diene monomer (EPDM) construction for resistance to the radiological attributes of the waste. Material selection, transfer line design, and fabrication shall maximize the useful service life of finished assemblies towards a service life goal of three years. 
TABLE 1

CHEMICAL CONSTITUENTS OF UNDILUTED WASTE FOR S/SX TANK FARMS

\begin{tabular}{|l|c|c|c|}
\hline \multicolumn{1}{|c|}{ Chemical Constituent } & $\begin{array}{c}\text { Concentration, } \\
\mathbf{m g} / \mathbf{g}^{\mathbf{s}}\end{array}$ & $\begin{array}{c}\text { Concentration, } \\
\mathbf{m g} / \mathbf{k g}\end{array}$ & $\begin{array}{c}\text { Concentration, } \\
\mathbf{m g} / \mathbf{L}\end{array}$ \\
\hline Sodium Hydroxide ${ }^{2}$ & 156 & 156,000 & 211,000 \\
\hline Ammonia & 1.33 & 1,330 & 1,800 \\
\hline Total Organic Carbon & 4.75 & 4,750 & 6,410 \\
\hline \multicolumn{1}{|c|}{ Organic Constituent } & & & \\
\hline Acetate & 2.03 & 2,030 & 2,740 \\
\hline Formate & 2.17 & 2,170 & 2,930 \\
\hline Glycolate & 0.739 & 739 & 998 \\
\hline Oxalate & 7.93 & 7,930 & 10,700 \\
\hline
\end{tabular}

Notes:

'Calculated assuming a specific gravity of 1.35

${ }^{2}$ Based on hydroxide analysis, with a conversion factor of 2.35

TABLE 2

CHEMICAL CONSTITUENTS OF UNDILUTED WASTE FOR U TANK FARM

\begin{tabular}{|l|c|c|c|}
\hline \multicolumn{1}{|c|}{ Chemical Constituent } & $\begin{array}{c}\text { Concentration, } \\
\mathbf{m g} / \mathbf{g}^{\mathbf{1}}\end{array}$ & $\begin{array}{c}\text { Concentration, } \\
\mathbf{~} \mathbf{g} / \mathbf{k g}\end{array}$ & $\begin{array}{c}\text { Concentration, } \\
\mathbf{m g} / \mathbf{L}\end{array}$ \\
\hline Sodium Hydroxide & & 116,000 \\
\hline Ammonia & 83.0 & 83,000 & 1,800 \\
\hline Total Organic Carbon & 1.29 & 1,290 & 48,400 \\
\hline \multicolumn{1}{|c|}{ Organic Constituent } & 34.6 & 34,600 & 1,540 \\
\hline Acetate & & & 13,400 \\
\hline Formate & 1.10 & 1,100 & 12,200 \\
\hline Glycolate & 9.57 & 9,570 & 3,080 \\
\hline Iminodiacetate & 8.71 & 8,710 & 1,340 \\
\hline Nitrilotriacetate & 2.20 & 2,200 & 10,300 \\
\hline Oxalate & 0.957 & 957 & \\
\hline
\end{tabular}

Notes:

'Calculated assuming a specific gravity of 1.4

${ }^{2}$ Based on hydroxide analysis

- The primary hose shall have a nominal inside diameter of 2".

- The secondary hose shall have a nominal inside diameter of 4".

- The minimum bend radius of primary and secondary hoses shall not be greater than 16 ".

- Primary hose and any appurtenant heat tape shall be designed to be pulled through the secondary line without mechanical damage to any component. The design shall incorporate the static dissipative features described above. 
- Primary and secondary hoses, and any appurtenant insulation or heat tracing, shall be suitable for installation in an outdoor environment, in direct contact with soil, shaded from direct sunlight, with an ambient temperature range of -25 degrees $F$ to 130 degrees $F$.

- The transfer line assemblies shall be capable of operating over an ambient temperature range of 20 degrees $\mathrm{F}$ to 110 degrees $\mathrm{F}$.

- Primary and secondary hoses shall be suitable for use at process fluid temperatures ranging from 80 degrees $\mathrm{F}$ to 180 degrees $\mathrm{F}$. Transfer line assemblies will incorporate heat tracing and insulation to assist in maintaining this process temperature. The heat tracing and insulation shall be designed to only maintain the temperature of the waste in the primary hose at or above 110 degrees F. Hot water flushing will be required to initially pre-heat the primary hose to a minimum of 110 degrees F. Self regulating electrical heat tracing shall be wrapped in a helical manner around the exterior of the primary hose. The exterior surface of the primary hose, and any appurtenant overwrap required for dissipation of static charges, shall be suitable for direct continuous contact with specified heat tracing ( 155 degrees $F$ contact temperature).

- The design of the transfer hose assemblies shall be per ASME B31.3, Process Piping; ASME B16.5, Pipe Flanges and Flanged Fittings and Rubber Manufacturers of America Hose Handbook (RMA IP-2). Testing methods shall be per ASTM D380, Standard Test Methods for Rubber Hose. The latest issue and addenda of these national standards and specifications shall govern.

- The secondary hose which functions as a secondary containment barrier to the primary hose shall comply with the WAC 173-303-640 (4) "Containment and detection of releases".

- The system design shall be capable of detecting a leak of two to three gallons per minute within twenty four hours [WAC 173-303-604 (4) (C) (iii)].

- The secondary hose shall be equipped with four inch male national pipe thread (NPT) fittings that can be connected with a flushing system to clear any primary system leaks that may develop [WAC 173-303-604 (4) (C) (iv)].

\section{Radiological Design Criteria}

- The hose-in-hose transfer system shall be designed to keep personnel exposures As Low As Reasonably Achievable (ALARA) in accordance with RPP-PRO-1621, "ALARA Decision-Making Methods" and RPP-PRO-1622, "Radiological Design Review Process".

- The hose-in-hose transfer system shall be designed to simplify the cut-up, dismantlement, removal and packaging of structures, systems and components in accordance with RPPPRO-1622.

- The hose-in-hose transfer system shall be designed such that access controls to radiation and high-radiation areas meet the requirements of HNF-5183 (latest revision), Tank Farms Radiation Control Manual. 


\section{Vehicular Traffic Criteria}

- The transfer line assemblies shall be installed such as to minimize impacts to vehicular traffic restrictions in and around the tank farms and shall meet the requirements of HNFSD-WM-TSR-006, Rev. 1-H, Section 5.12, Transfer Controls (concrete barriers shall be placed around the overground portion of each hose-in-hose assembly).

- There shall be no significant load placed on the installed transfer line assemblies from any vehicular traffic. Hose-in-hose assemblies will be protected from vehicular traffic by placing assemblies in a shallow trench and installing steel plate over the assemblies except where the hose-in-hose assemblies come out of the trench at the pit walls.

\section{Electrical power}

- Electrical power shall be routed and supplied to the hose-in-hose transfer system in accordance with the NFPA 70, 1999 National Electrical Code requirements.

- Electrical power conduit and wiring shall be designed and constructed to allow easy disconnection and removal when no longer required.

\section{Structural}

- Structural components shall be designed in accordance with the ninth edition of the American Institute of Steel Construction (AISC) manual. 


\section{APPENDIX B}

\section{ACCEPTANCE FOR BENEFICIAL USE CHECKLIST}

Note: The acceptance for beneficial use (ABU) checklist that follows identifies the minimum documentation that is required to be completed prior to turnover of the hose-in-hose transfer system to Operations for beneficial use. Objective evidence of completion of the documentation, such as citation of an Engineering Data Transmittal (EDT) releasing a supporting document, will be required. As a minimum, official turnover requires the approval/agreement of West Tank Farms Operations, Single Shell Tank Engineering, and Maintenance. 


\section{ACCEPTANCE FOR BENEFICIAL USE CHECKLIST}

\section{ENGINEERING}

$[\mathrm{X}$ ] Engineering Task Plan

[X] Activity Schedule

I J Final Safety Analysis Report

[ ] Interim Safety Basis - update

[X] Safety Assessment

[X] Safety Equipment List

[ : Operational Safety Requirements - or update existing

[ ] Operational Safety Document (s) - or update existing

[X] Funcrional Requirements \& Technical Criteria

[ ] System Design Description

( $X$ i Test Plan/Specifications

$[\mathrm{x}]$ Acceptance Test Procedures and Final Test Report

[ ] Operational Test Procedures and Final Test

Report

( ) Environmental Impact Statement

1) Environmental Report

[ ] Environmental Permit

[ ] Hazardous Waste Disposal $\mathrm{Plan} /$ Procedures

[ ] Solid Waste Disposal Plan/Procedure

[X] Stress/Seismic Analysis

[ ] Stress/Design Report

( ) Design Specifications/Report

[X] Equipment Specifications

[X] Procurement Specifications

l ] Construction Specification

l) Essential Material Specifications

(X) Final Design Drawings

[X] Installation Drawings

( ) Installation Work Plan Approval

[X] As-built Drawings

$[\mathrm{X}]$ interface Contro]. Drawings

[ ] IEFD Drawings

[X] Systems Drawings

[X] Drawing Tree

[X] Incorporate Outstanding Project Generated ECNS

[ ] Balance of Plant Instruments

[ ] Safety/Enviŗonmental Compliance Matrix

1 ] Hard to find information including PNNL

Reports, NOC Letters, Other Letter reports, etc.

[ I project will modify $\mathrm{S} / \mathrm{SX}$ Farm Index to include Project Drawings, specifications, and vendor index [ ] Project Index listing all drawings, documents, etc. required for this project. This index will be the final ABU.

[X] Commercial grade dedications per HNF-IP-0842, IV 3.11

[ ] Converted vendor drawings into issued Hanford Plant Drawings

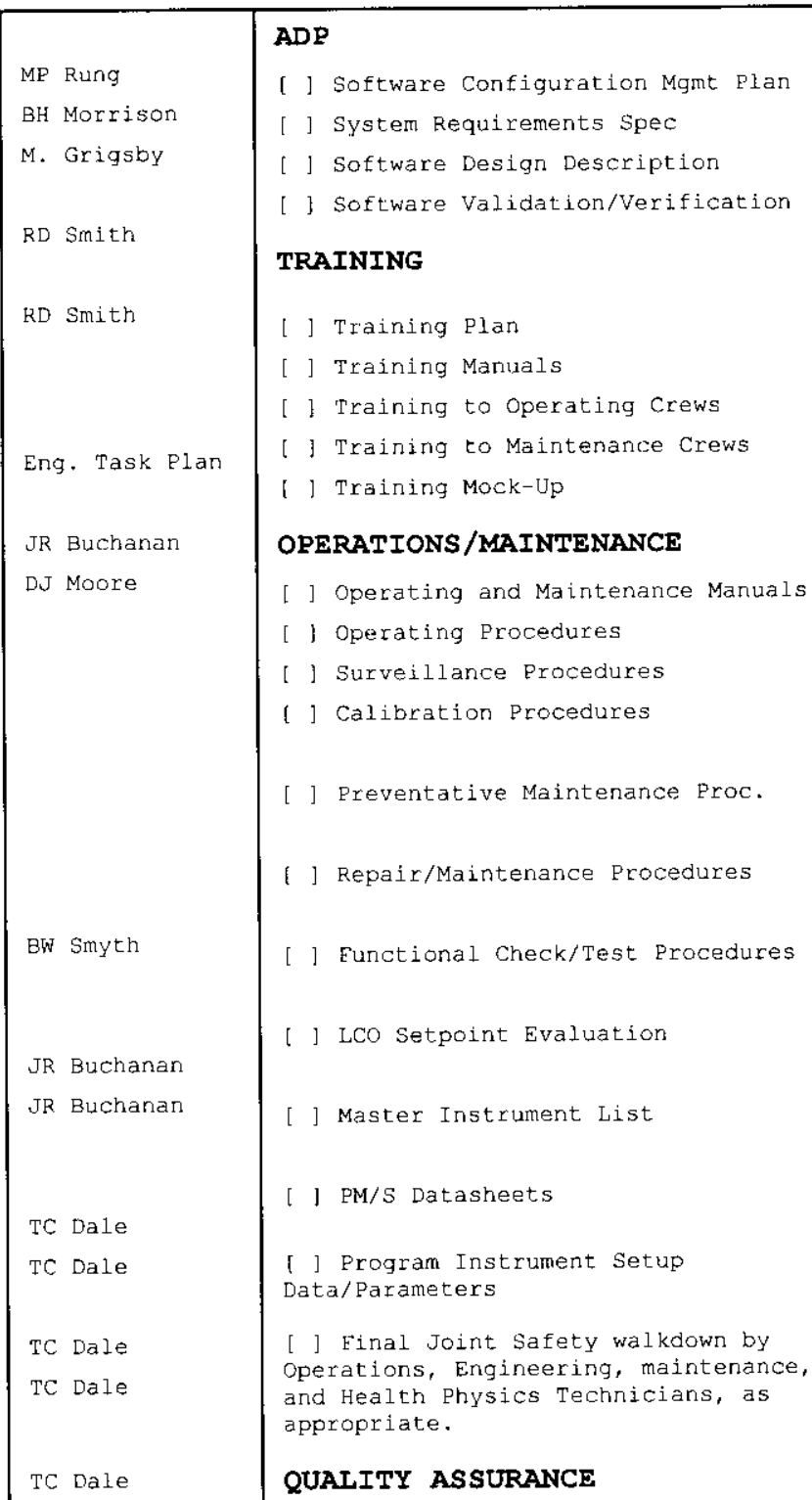

\section{PROCUREMENT}

[X] Inspection Plan

[ I QAPP

( ] $\mathrm{QAP}_{\mathrm{J}} \mathrm{B}$

[X] Vendor Information Files (VI)

MC Tipps

[ ] Comprehensive Equip. List (MEL)

[ ] Spare Parts List

1 ] Spare Parts in Stock 
RPP-6153 Rev. 1

APPENDIX C

SCHEDULE 


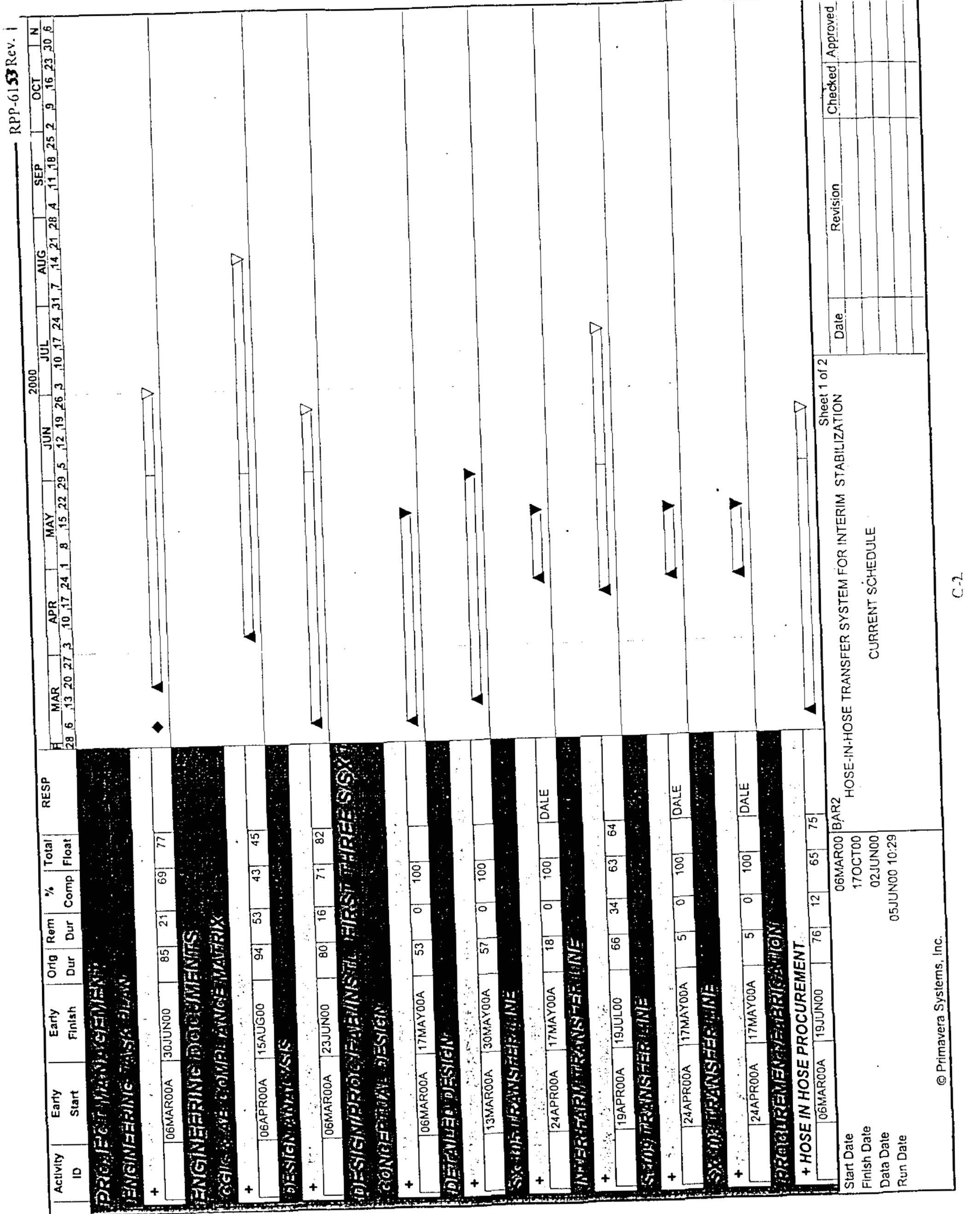




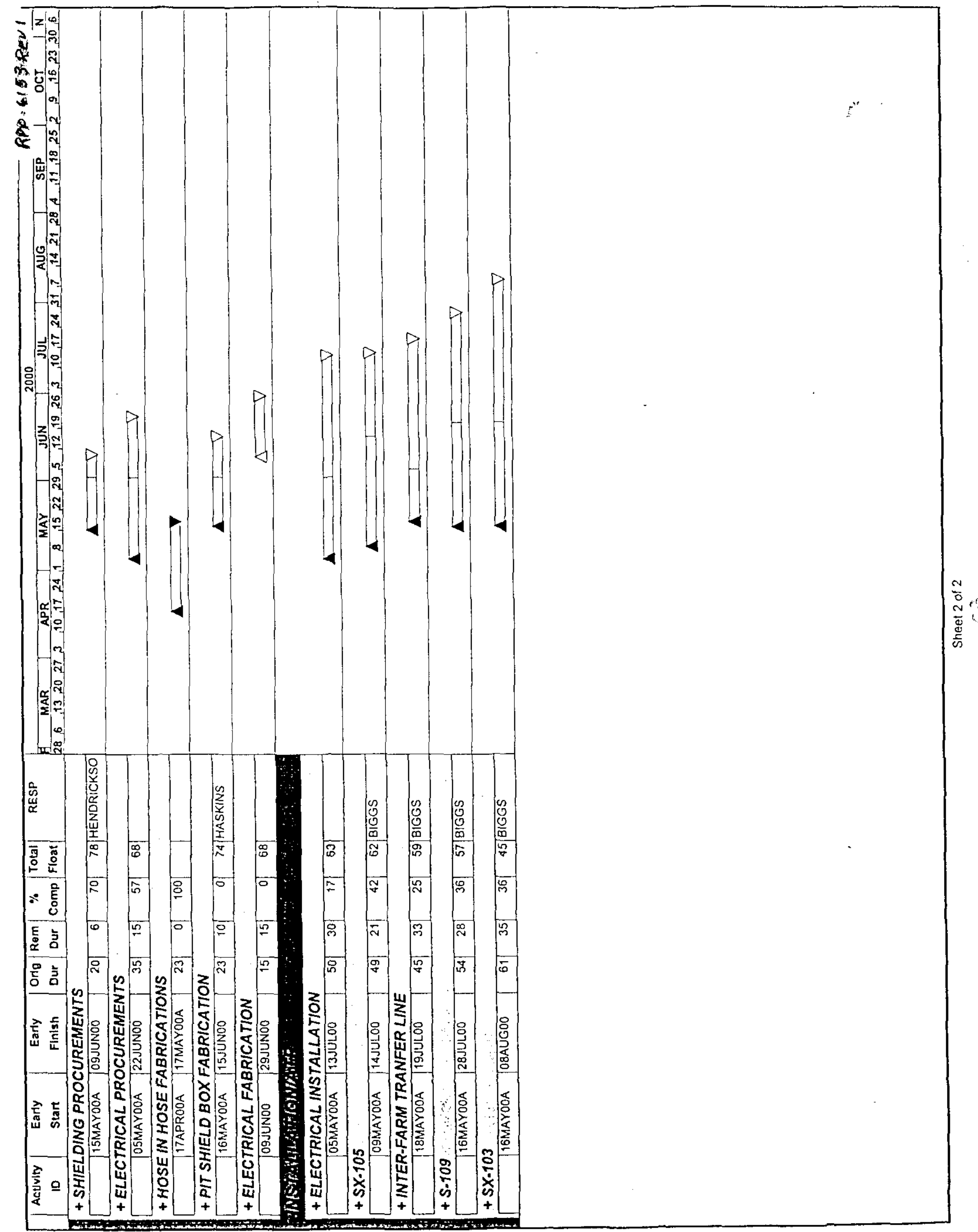




\section{APPENDIX D}

CHG Interoffice Memo File No. 74B20-00-047

Chemical Characteristics for Liquid Waste in U Tank Farm

CHG Interoffice Memo File No. 74B20-00-048

Chemical Characteristics for Liquid Waste in S and SX Tank Farms 
From: Data Development and Interpretation

74B20-00-047

Phone: 373-1027

Date: August 11, 2000

Subject: CHEMICAL CHARACTERISTICS FOR LIQUID WASTE IN U TANK FARM

To:

C. E. Hanson S7-70

Copies:

G. A. Barnes

$57-70$

J. R. Buchanan

S7-70

J. G. Field

R2-12

L. A. Fort

R2-12

W. F. Zuroff

S7-24

LMS File/LB

References:

(1) "Sample Analysis/Tank Results RPP-241," available on the Tank Characterization Database at http://twins.pnnl.gov/data/datamenu.htm. dated, August 9, 2000.

(2) RPP-6028, "Specification for Hose in Hose Transfer Lines for Hanford's Interim Stabilization Project," Rev. 0, dated April 3, 2000.

The purpose of this memo is to document the bounding chemical concentrations of the liquid waste in tanks 241-U-106, 241-U-107, 241-U-108, and 241-U-111 for the Interim Stabilization Project procurement specification of a hose-in-hose transfer line for use on these tanks (Reference 2). The chemical constituents for which these concentrations were requested are: sodium hydroxide, ammonia, organic carbon, and organic compounds.

Table 1 lists the highest observed concentrations of sodium hydroxide and total organic carbon in liquid waste samples from tanks 241-U-106, 241-U-107, 241-U-108, and 241-U-111 (Reference 1 and Attachment). Table 2 lists the highest concentrations of specific organic compounds observed in these samples. Because of limited ammonia data for these tanks, the ammonia value in Table 1 is taken from the highest ammonia concentration observed in liquid waste samples from tanks containing wastes similar to the wastes in tanks 241-U-106, 241-U-107, 241-U-108, and 241-U-111. Other than the organic compounds listed in Table 2, there are no organic . analysis data available for tanks 241-U-106, 241-U-107, 241-U-108, 241-U-111 or for tanks containing similar wastes.

Table 1. Chemical Constituents of Undiluted Waste

\begin{tabular}{|l|c|c|c|}
\hline \multicolumn{1}{|c|}{ Constituent } & $\begin{array}{c}\text { Concentration, } \\
\mathbf{m g} / \mathbf{g}^{\mathbf{1}}\end{array}$ & $\begin{array}{c}\text { Concentration, } \\
\mathbf{m g}^{\prime} \mathbf{k g}^{1}\end{array}$ & $\begin{array}{c}\text { Concentration, } \\
\mathbf{m g} / \mathbf{L}\end{array}$ \\
\hline Sodium Hydroxide & 83.0 & 83,000 & 116,000 \\
\hline Ammonia & 1.29 & 1,290 & 1,800 \\
\hline Total Organic Carbon & 34.6 & 34,600 & 48,400 \\
\hline
\end{tabular}

Notes:

'Calculated assuming a specific gravity of 1.4

${ }^{2}$ Based on hydroxide analysis 
- C. E. Hanson

$74320-00-047$

Page 2

August 11, 2000

Table 2. Organic Compounds Identified

\begin{tabular}{|l|c|c|c|}
\hline \multicolumn{1}{|c|}{ Constituent } & $\begin{array}{c}\text { Concentration, } \\
\mathbf{m g} / \mathbf{g}^{\mathbf{1}}\end{array}$ & $\begin{array}{c}\text { Concentration, } \\
\mathbf{m g} \mathbf{k g}\end{array}$ & $\begin{array}{c}\text { Concentration, } \\
\mathbf{m g} / \mathbf{L}\end{array}$ \\
\hline Acetate & 1.10 & 1,100 & 1,540 \\
\hline Formate & 9.57 & 9,570 & 13,400 \\
\hline Glycolate & 8.71 & 8,710 & 12,200 \\
\hline Iminodiacetate & 2.20 & 2,200 & 3,080 \\
\hline Nitrilotriacetate & 0.957 & 957 & 1,340 \\
\hline Oxalate & 7.36 & 7,360 & 10,300 \\
\hline
\end{tabular}

Note:

'Calculated assurning a specific gravity of 1.4

If there are any questions regarding this information, please contact me at 373-1027 or Mr. J. G. Field, on 376-3753.

Lh track:

L. M. Sasaki, Engineer II

Data Development and Interpretation

dmn

Attachment 
From: Data Development and Interpretation

Phone: $373-6343$

Date: $\quad$ August 11,2000

Subject: CHEMICAL CHARACTERISTICS FOR LIQUID WASTE IN S AND SX TANK FARMS

To:

C. E. Hanson

S7-70

cc:

G. A. Barnes

57.70

J. R. Buchanan

J. G. Field

L. A. Fort

S7-70

W. F. Zuroff

R2-12

R2-12

TLL File/LB

S7-24

References: (1) "Sample Analysis/Tank Results RPP-241," available on the Tank Characterization Database at http://twins.pnl.gov/data/datamenu.htm, dated August 9, 2000.

(2) RPP-6028, "Specification for Hose in Hose Transfer Lines for Hanford's Interim Stabilization Project," Rev. 0, dated April 3, 2000.

The purpose of this memo is to document the bounding chemical concentrations of the liquid waste in tanks 241-S-101, 241-S-107, 241-S-109, 241-S-111, 241-S-112, 241-SX-101, 241-SX-102, 241-SX-103, and 241-SX-105 for the Interim Stabilization Project procurement specification of a hose-in-hose transfer line for use on these tanks (Reference 2). The chemical constituents for which these concentrations were requested are: sodium hydroxide, ammonia, organic carbon, and organic compounds.

Table 1 lists the highest observed concentrations of ammonia, sodium hydroxide and total organic carbon in liquid waste samples from tanks 241-S-101, 241-S-107, 241-S-109, 241-S-111, 241-SX-101, 241-SX-102, 241-SX-103, and 241-SX-105 (Reference 1). Analytical data from tank 24l-S-112 was not available, however the waste in tank 241-S-112 is well represented by the values of the other tanks listed. Table 2 lists the highest concentrations of specific organic compounds observed in these samples. Other than the organic compounds listed in Table 2, there are no organic analysis data available for tanks 241-S-101, 241-S-107, 241-S-109, 241-S-111, 241-SX-101, 241-SX-102, 241-SX-103, and 241-SX-105 or for tanks containing similar wastes. The average specific gravity of 1.35 measured for tanks 241-S-101, 241-S-107, 241-S-109, 241-S-111, 241-SX-101, 241-SX-102, 241-SX-103, and 241-SX-105 was used to convert liquid units to solid units. 
Table 1. Chemical Constituents of Undiluted Waste

\begin{tabular}{|l|c|c|c|}
\hline Constituent & $\begin{array}{c}\text { Concentration, } \\
\mathbf{m g} / \mathbf{g}^{\mathbf{1}}\end{array}$ & $\begin{array}{c}\text { Concentration, } \\
\mathbf{m g} / \mathbf{k g}^{\mathbf{1}}\end{array}$ & $\begin{array}{c}\text { Concentration, } \\
\mathbf{m g} / \mathbf{L}\end{array}$ \\
\hline Sodium Hydroxide & 156 & 156,000 & 211,000 \\
\hline Ammonia & 1.33 & 1,330 & 1,800 \\
\hline Total Organic Carbon & 4.75 & 4,750 & 6,410 \\
\hline
\end{tabular}

Notes:

${ }^{1}$ Calculated assuming a specific gravity of 1.35

${ }^{2}$ Based on hydroxide analysis, with a conversion factor of 2.35

Table 2. Organic Compounds Identified

\begin{tabular}{|l|c|c|c|}
\hline \multicolumn{1}{|c|}{ Constituent } & $\begin{array}{c}\text { Concentration, } \\
\mathbf{m g} / \mathbf{g}^{\mathbf{1}}\end{array}$ & $\begin{array}{c}\text { Concentration, } \\
\mathbf{m g} / \mathbf{k g}^{1}\end{array}$ & $\begin{array}{c}\text { Concentration, } \\
\mathbf{m g} / \mathbf{L}\end{array}$ \\
\hline Acetate & 2.03 & 2,030 & 2,740 \\
\hline Formate & 2.17 & 2,170 & 2,930 \\
\hline Glycolate & 0.739 & 739 & 998 \\
\hline Oxalate & 7.93 & 7,930 & 10,700 \\
\hline
\end{tabular}

Note:

${ }^{2}$ Calculated assuming the average specific gravity of 1.35

If there are any questions regarding this information, please contact me at 373-6343 or Mr. J. G. Field, on 376-3753.

QhAsere'

T. L. Lauricella, Scientist

Data Development and Interpretation

dmn 